\title{
Acceptability, Nutritional Quality and Contribution of Vegetable-Enriched Products to Nutrient and Energy Requirements of School Children Aged 5 to 13 Years
}

\author{
Nwatarali Philomena Onwuamaeze, Acham Hedwig*, Nakimbugwe Dorothy \\ Department of Food Technology and Nutrition, School of Food Technology, Nutrition and Bio-Systems Engineering, Makerere \\ University, Kampala, Uganda \\ Email: `hacham@caes.mak.ac.ug
}

How to cite this paper: Onwuamaeze, N.P., Hedwig, A. and Dorothy, N. (2017) Acceptability, Nutritional Quality and Contribution of Vegetable-Enriched Products to Nutrient and Energy Requirements of School Children Aged 5 to 13 Years. Food and Nutrition Sciences, 8, 242-266. https://doi.org/10.4236/fns.2017.82016

Received: May 25, 2016

Accepted: February 21, 2017

Published: February 24, 2017

Copyright $\odot 2017$ by authors and Scientific Research Publishing Inc. This work is licensed under the Creative Commons Attribution-NonCommercial International License (CC BY-NC 4.0). http://creativecommons.org/licenses/by-nc/4.0/ (c) (i) \&) Open Access

\begin{abstract}
Micronutrient deficiency (MD) is a problem among schoolchildren which, in addition to other effects, also affects their intellectual abilities. Inclusion of vegetables to food formulations can help to reduce MD because they contain vital micronutrients which are required for improved school performance. This study aimed at evaluating acceptability, determining the nutritional quality and estimating the contribution of vegetable enriched products to the Recommended Dietary Allowance (RDA) of schoolchildren (5 to 13 years). The vegetables used were red and green amaranth leaves, orange fleshed sweet potato and pumpkin. Selection of vegetables was based on richness in micronutrients; local availability and consumption levels in Uganda; and their underutilization status particularly in processed form. Each of the vegetables was preprocessed and incorporated separately into soybean and grain amaranth in the ratio of 10:40:50, respectively, to improve the nutrient and energy density of the formulations. Sensory screening of formulations in a range of products (porridges, soups and snacks) revealed that orange fleshed sweet potato formulation was most preferred for porridge as well as for snacks (at 30:70 ratio of orange fleshed sweet potato composite to wheat flour); while red amaranth leaves composite was most preferred for soup. When tested for acceptability, nutritional quality, as well as contribution to the RDA (for vitamin A, iron, zinc, protein and energy) for schoolchildren 5 to 13 years, acceptability tests and nutritional quality of food products from the formulations were highly rated compared to commercial products (pure maize porridge, wheat based soup and $100 \%$ refined wheat flour snacks). All products from the two formulations contributed favourably to vitamin A, iron, zinc and protein requirements of children (5 to 13 years). Based on these findings, orange fleshed
\end{abstract}


sweet potato composite flour can be recommended for making porridge, and can substitute $(30 \%)$ for wheat flour in making snacks; while red amaranth leaf composite flour can be recommended for making soups.

\section{Keywords}

Micronutrient, School Age Children, Vegetables, Acceptability, Nutritional Quality

\section{Introduction}

Today micronutrient nutrition is gaining much recognition worldwide due to large spread of micronutrient deficiencies (MD's) especially in developing countries. Roughly, two billion people (about one third of the world's population) are deficient in one or more micronutrients [1]. MD can have major adverse health effects contributing to growth impairments, immune incompetence, mental and physical development retardation, and poor reproductive outcomes [2] [3] that cannot always be reversed by nutrition interventions [1]. The global concern of MD among children is iron, vitamin A and zinc [4] of which the deficiency is a problem among school going children.

Vegetables are essential for combating MD in the developing world; they are rich in vital micronutrients such as carotenes, vitamins and minerals, as well as dietary fibre [5]. Vegetables such as pumpkin, orange-fleshed sweet potatoes (OFSP) and leafy vegetables like red and green amaranth leaves (A. cruentus and A. lividus, respectively), are food sources of pro vitamin A carotenoids [6] and lots of minerals which can contribute effectively to improving vitamin A and mineral intakes, including iron and zinc. Raw amaranth leaves alone contain 2.46 grams of protein, $2.32 \mathrm{mg}$ of iron, $0.90 \mathrm{mg}$ of zinc, $146 \mu \mathrm{g}$ of vitamin A RAE and $23 \mathrm{Kcal}$ of energy per 100 grams of sample [7]. Similarly, raw orange fleshed sweet potato contains 1.57 grams of protein, $0.61 \mathrm{mg}$ of iron, $0.30 \mathrm{mg}$ of zinc, $709 \mu \mathrm{g}$ of vitamin A RAE and $86 \mathrm{Kcal}$ of energy per 100 grams of sample; and raw pumpkin contains 1.00 grams of protein, $0.80 \mathrm{mg}$ of iron, $0.32 \mathrm{mg}$ of zinc, $426 \mu \mathrm{g}$ of vitamin A RAE and $26 \mathrm{Kcal}$ of energy per 100 grams of sample [7]. These vegetables can be blended with legumes and/or cereal crops (including grain amaranth and soybean) in food formulations targeted for children so as to improve the nutrient and energy densities. For example, raw 100 grams portion of grain amaranth contains 13.5 grams of protein, $7.61 \mathrm{mg}$ of iron, $2.87 \mathrm{mg}$ of zinc, $2 \mu \mathrm{g}$ of vitamin A RAE and $371 \mathrm{Kcal}$ of energy [7] and this grain has been used for feeding severely malnourished children [8] while raw mature soybeans contain 36.5 grams of protein, $15.7 \mathrm{mg}$ of iron, $4.9 \mathrm{mg}$ of zinc, and $446 \mathrm{Kcal}$ of energy per 100 grams of sample [7].

The aim of this work was therefore to evaluate the acceptability, nutritional quality and estimated contribution of vegetable enriched products to the RDA of school age children (5 to 13 years). 


\section{Materials and Methods}

\subsection{Raw Materials, Source and Justifications for Inclusion}

The raw materials used were purchased within Kampala, Uganda. Red and green amaranth ( $A$. cruentus and A. lividus, respectively) leaves, soybeans and pumpkin (Cucurbita maxima) were purchased from fresh food markets in Kampala. Grain amaranth flour (golden amaranth) was obtained from Nutreal Limited in Kampala, while orange fleshed sweet potato (OFSP) (Ejimula) was procured from a farmer in Bombo; about 20 kilometers from Kampala. The raw materials were selected based on their content of nutrients of public health concern which include iron, vitamin A and Zinc; as well as their protein and energy content. Besides nutritional endowment; red and green amaranth leaves were selected because they are the most abundant and commonly consumed leafy vegetables in Kampala. On the contrary, OFSP and pumpkin were selected so as to formulate products that can lead to popularization of their use as they are locally grown but their consumption is generally limited.

The vegetables (red and green amaranth leaves, pumpkin mesocarp and OFSP) are generally rich in micronutrients especially vitamin A [6] but are not quite high in iron, zinc and protein so they were blended with soybean which also contains monounsaturated oil that helps in the absorption of fat soluble vitamin A. Grain amaranth (GA) was added as it has high content of iron, energy and starch which is necessary for porridge and soup consistency. GA was also selected to promote its utilization and consumption.

\subsection{Preparation and Processing of the Raw Materials}

\subsubsection{Red and Green Amaranth Leaves \\ Preparation}

The processing method used was similar to that of [9]. The fresh amaranth leaves were sorted and graded to remove damaged and discolored ones, washed thoroughly and rinsed with potable water. The washed vegetables were pretreated with sodium metabisulphite solution at 2 grams/litre $(0.2 \mathrm{w} / \mathrm{v})$ for 1 minute to avoid browning then spread on a clean tray with foil and dried at temperature of $65^{\circ} \mathrm{C}$ for 12 hours using a cabinet dryer (B. Master SR 2046, TAURO Italy) until brittle.

\section{Processing}

The dried vegetable leaves were milled into flour using a locally made hammer millin the laboratory, sieved through a $50-100$ mesh screen, packed into a clean dry bag, sealed and kept in the cold room at $2^{\circ} \mathrm{C}$ until use.

\subsubsection{Soybeans}

\section{Preparation}

Soybeans were processed according to the method of [10] with some modifications. Once purchased, it was sorted to remove damaged ones, stones and dirt.

\section{Processing}

Soybeans were soaked for 8 hours, washed several times with water, dehulled 
manually, blanched at $90^{\circ} \mathrm{C}$ [11] for 10 minutes and dried at $65^{\circ} \mathrm{C}$ for 24 hours using cabinet dryer (B. Master SR 2046, TAURO, Italy). The dried soybeans were roasted using infrared food oven (GU-6 A80037, Malaysia) at $180^{\circ} \mathrm{C}$ for 20 minutes, cooled, milled into flour using a locally made hammer mill, packed into a clean cellophane bag and refrigerated at $2^{\circ} \mathrm{C}$ until use.

\subsubsection{Orange Fleshed Sweet Potato (OFSP) \\ Preparation}

The processing method used was similar to that reported by [12] with modifications. The OFSP were sorted to remove damaged ones and dirt, peeled manually, washed several times with potable water and sliced using a locally made chipping machine. The chips, were dipped in aqueous $0.2 \%(\mathrm{w} / \mathrm{v})$ sodium metabisulphite solution for 1 minute to avoid enzymatic browning during drying and storage and then dried using cabinet dryer (B. Master SR 2046, TAURO Italy) at a temperature of $65^{\circ} \mathrm{C}$ for 7 hours.

\section{Processing}

The dried flakes were milled into flour using a locally made hammer mill, packed into a plastic bag and stored in the cold room at $2^{\circ} \mathrm{C}$ until use.

\subsubsection{Pumpkin}

\section{Preparation}

The processing method for pumpkin was similar to the method used by [13]. The pumpkins were manually peeled with a knife so as to remove the outer layer. The seeds and peel were discarded while the flesh was chipped with a locally made chipping machine, soaked in $0.2 \%(\mathrm{w} / \mathrm{v})$ sodium metabisulphate for 1 minute to avoid enzymatic browning and dried using cabinet dryer (B. Master SR 2046, TAURO Italy) at $70^{\circ} \mathrm{C}$ for 15 hours [14].

\section{Processing}

The dried pumpkin chips were milled into flour using a locally made hammer mill, packed into a plastic bag and stored in a cold room at $2^{\circ} \mathrm{C}$ until use.

\subsection{Blending of the Flours}

Concept 4 Creative Software [15] was used to formulate the blends that would contribute to vitamin A, iron, zinc, protein and energy requirements of children aged 5 to 13 years. The reference nutrient contents of the supposed raw materials used in this study (in flour form) were derived from combination of literatures; afterwards they were run through the software to generate those nutrient levels (Table 1). The orange fleshed sweet potato (OFSP), pumpkin, red amaranth

Table 1. Nutrient compositions and energy content (per $100 \mathrm{~g}$ ) of the orange fleshed sweet potato (OFSP) composite and red amaranth composite as predicted by concept 4 software.

\begin{tabular}{cccccccc}
\hline $\begin{array}{c}\text { Composite name } \\
\text { (abbreviations) }\end{array}$ & $\begin{array}{c}\text { Vegetables } \\
(10 \%)\end{array}$ & $\begin{array}{c}\text { Soy bean } \\
\text { flour (\%) }\end{array}$ & $\begin{array}{c}\text { Grain Amaranth } \\
\text { flour (\%) }\end{array}$ & $\begin{array}{c}\text { Energy Protein } \\
\text { (Kcal) }\end{array}$ & $\begin{array}{c}\text { Vitamin A } \\
(\mathbf{g})\end{array}$ & $\begin{array}{c}\text { Fe } \\
(\mathbf{m c g})\end{array}$ & $\begin{array}{c}\text { Zinc } \\
(\mathrm{mg})\end{array}$ \\
$(\mathrm{mg})$
\end{tabular}

OSG = Orange fleshed sweet potato + soybean + grain amaranth, RSG = Red amaranth leaves + soybean+ grain amaranth 
leaves and green amaranth leaves were incorporated at $10 \%$ level individually to soybean (40\%) and grain amaranth (50\%) which initially resulted to four formulations (OFSP composite OSG, Pumpkin composite PSG, Red amaranth composite RSG and Green amaranth composite GSG); respectively (Table 1). The four formulations were screened for products including porridge, soup and snacks-chapattis.

\subsection{Preparation of the Foods Incorporating the Vegetable Enriched Composite Flours}

Porridges, soups and snacks-chapattis incorporating the vegetable enriched composite flours were prepared. The choice of these products was influenced by their likelihood to be adopted as similar foods are commonly given to school age children. For preparation of chapattis, 30\% of the vegetable-enriched composite flours were added to $70 \%$ of wheat flour [16] and other ingredients (Table 2). The ingredients were thoroughly mixed by hand to make dough. Portions of 65 grams were flattened using a roller pin (to a thickness of about $0.2 \mathrm{~cm}$ and diameter of $18 \mathrm{~cm}$ ) then shallow fried for about 3 minutes.

For soup preparation, all the dry spice ingredients ( 22 grams) were mixed with 78 grams of each of the composite flours (Table 3 ). The soup mixtures (100

Table 2. Recipe used for preparation of vegetable enriched chapattis.

\begin{tabular}{cc}
\hline Ingredients & Proportions \\
\hline Wheat flour (grams) & 700 \\
Composite flours (grams) & 300 \\
Water (ml) & 500 \\
Grated carrot (grams) & 78 \\
Sunflower oil (sun seed, ml) & 65 \\
Grated onions (grams) & 43 \\
Table salt (grams) & 16 \\
\hline
\end{tabular}

Adapted from [16] [17] with modifications.

Table 3. Recipe used for preparation of vegetable enriched soup.

\begin{tabular}{cc}
\hline Ingredients & Proportions \\
\hline Composite flours (grams) & 78.0 \\
Water (ml) & 800.0 \\
Sun flower oil (sun seed, ml) & 10.0 \\
Table salt (grams) & 8.0 \\
Dried tomato (grams) & 5.0 \\
Dried grated onions (grams) & 2.5 \\
Curry powder (grams) & 2.0 \\
Dried carrot (gram) & 1.0 \\
Spices (pilau powder, gram) & 1.0 \\
Dried green pepper (gram) & 0.5
\end{tabular}


grams) were cooked with $800 \mathrm{ml}$ of water and $10 \mathrm{ml}$ of sunflower vegetable oil for 10 minutes. For porridge preparation (Table 4), the flour rates (FR) used were those determined to result in drinkable viscosity range $(2500-3000 \mathrm{cP})$ [18] [19] for children. The porridges were cooked for 10 minutes and 30 grams of sugar were added per litre of porridge.

Based on the screening result, it was found that the two most accepted formulations were: OFSP composite, denoted as OSG (which comprised of 10\% OFSP, $40 \%$ soybean and $50 \%$ grain amaranth) for porridge and chapattis and; red amaranth composite, denoted as RSG (which comprised of 10\% red amaranth leaves, $40 \%$ soybean and $50 \%$ grain amaranth) for soup. Therefore these two formulations were adopted and used in this study. These two formulations were evaluated for sensory acceptability, nutritional quality and estimated contribution of the products to the vitamin $\mathrm{A}$, iron, zinc, protein and energy requirements of children aged 5 - 13 years.

\subsection{Acceptability Test of Vegetable Enriched Products in Comparison to Commercial Products}

Test for acceptability was done with the: OFSP composite for porridge and chapatti preparations; red amaranth composite for soup preparation in comparison to that of commercial products. The commercial products used in this study were maize porridge, chapattis made from $100 \%$ refined wheat flour and refined wheat flour based composite soup. These commercial products (maize porridge and $100 \%$ wheat flour chapattis) were selected because they are commonly consumed by both school children and adults in Uganda. Refined wheat flour based composite soup flour was selected as one of the few processed soup flours on the shelf and also according to sellers in supermarkets; it was among the most purchased soup flour in Kampala. The flour rate (FR) and viscosity of OFSP composite and maize porridges were determined (to meet the standard porridge viscosity requirement $2500-3000 \mathrm{cP}$ for children [18] [19] and the porridge was prepared using the FR derived. The commercial wheat flour composite soup (which contains other soup ingredients in the sachet) was prepared according to the manufacturer's specification that recommends mixing 60 grams (6\%) of soup flour in $850 \mathrm{ml}$ of water and cooking for 6 minutes while that of red amaranth composite soup was prepared by mixing 100 grams (of flour and soup mixtures) in $800 \mathrm{ml}$ of water (Table 3). Viscosities (cP) determination of the commercial products (maize porridge and wheat flour composite soup) was done with the same specifications used for the viscosity determination of the actual

Table 4. Recipe used for preparation of vegetable enriched porridge (based on their viscosity rate).

\begin{tabular}{cc}
\hline Ingredients & Proportions \\
\hline OFSP composite flours at 16\% flour rate & 160 grams of flour in $840 \mathrm{ml}$ of water \\
Other composite flours (PSG, RSG and GSG) at 15\% flour rate 150 grams of flour in $850 \mathrm{ml}$ of water \\
Sugar per litre of porridge & 30 grams \\
\hline
\end{tabular}


samples (section 2.6). The commercial chapatti was prepared using $100 \%$ wheat flour and the recipe used was according to a commercial producer's specification (Table 5) while the OFSP composite chapatti was prepared using 30\% OFSP composite flour and $70 \%$ wheat flour (Table 2). The ingredients for chapattis were thoroughly mixed by hand. A portion of 65 grams was flattened using a roller pin (to a thickness of about $0.2 \mathrm{~cm}$ and diameter of $18 \mathrm{~cm}$ ) then shallow fried for about 3 minutes.

The panel for evaluation of all the products consisted of 70 untrained school children from Makerere primary school in Kampala that assessed the products based on four sensory attributes colour, flavour, taste and overall acceptability. The scoring instructions were well explained to the panelist and questions were asked to ensure compliance. For ease of evaluation since they were young, evaluation was done using a 5-point hedonic scale, with $1=$ dislike extremely, $2=$ dislike slightly, $3=$ neither like nor dislike, $4=$ like slightly and $5=$ like extremely [20]. According to [21], a 5-point hedonic scale can be recommended for sensory evaluation by school children. The products for sensory evaluation were randomly coded before service.

\subsection{Viscosity Determination}

Viscosity in centipose $(\mathrm{cP})$ was determined using a Brookfield pro viscometer (Model DV-II Rheometer V2.0 RV; Middleboro, Massachusetts, USA) with spindle no 63 at speed of $30 \mathrm{rpm}$. During viscosity trial measurements some amount of flour were mixed with water (to meet the standard requirement 2500 $3000 \mathrm{cP}$ for porridge) and boiled for 10 minutes to gelatinize the starch. Viscosities were then read at $55^{\circ} \mathrm{C}$, the approximate temperature at which porridges are fed to children [22]. Viscosities of red amaranth composite soup were determined using $10 \%$ flour rate while that of the commercial soup were determined using 6\% FR (manufacturer's specification).

\subsection{Pasting Properties Determination}

Pasting properties of the flours were determined using a Rapid Visco Analyzer (RVA-4, Newport Scientific, Warrie-wood, Australia). Each flour (3.5 grams) was mixed with $25 \mathrm{ml}$ of water in an aluminum canister with a plastic paddle and mixed at $160 \mathrm{rpm}$, then exposed to the following temperature/time sequence:

Table 5. Recipe used for preparation of commercial chapattis.

\begin{tabular}{cc}
\hline Ingredients & Proportions \\
\hline Refined wheat flour (grams) & 1000 \\
Water (ml) & 500 \\
Vegetable oil (ml) & 75 \\
Fresh grated onions (grams) & 80 \\
Fresh grated carrots (grams) & 50 \\
Table salt (grams) & 18 \\
\hline
\end{tabular}

Recipe was according to a commercial producer's specification. 
heating to $50^{\circ} \mathrm{C}$ for $1 \mathrm{~min}$, heating from $50^{\circ} \mathrm{C}$ to $95^{\circ} \mathrm{C}$ for 4.42 minutes, holding at $95^{\circ} \mathrm{C}$ for 2.7 minutes, and cooling from $95^{\circ} \mathrm{C}$ to $50^{\circ} \mathrm{C}$ for 3.88 minutes. The apparent viscosity was expressed in rapid visco units (RVU). With the aid of thermocline for Microsoft platform attached to a computer [23], the following parameters were obtained from the plotted graphs and pasting profile: Pasting temperature, Peak viscosity, trough/holding strength, final viscosity, setback viscosity and break down viscosity.

\subsection{Nutritional Quality of OFSP Composite and Red Amaranth Composite Formulations and Products}

Orange fleshed sweet potato composite (OSG) and red amaranth composite (RSG) flours were analyzed for the key nutrients (vitamin A, iron and zinc); $\mathrm{HCl}$ extractability of zinc and iron; proximate composition and energy. The commercial samples used for comparison were equally analyzed for the key nutrients, proximate compositions and energy levels.

\subsubsection{Proximate Composition and Dietary Fibre Determination 1) Determination of moisture content}

Moisture was determined according to [24]. Two grams (2 g) of each sample (W1) was weighed into a dried crucible. The crucible and sample on it (W2) were then placed in a moisture extraction hot oven with a fan (GALLENKAMP SG93/08/850 size 2 , UK) at $98^{\circ} \mathrm{C}$ overnight. The dried samples were put into desiccators to cool and then weighed. The weight of the dried sample and crucible were denoted as $W 3$. The difference in weight was calculated as percentage moisture.

$$
\text { Percentage moisture }=W 2-W 3 \times 100 \div W 1
$$

where $W 2$ = Initial weight of empty dish + sample before drying

$W 1=$ weight of sample before drying

$W 3=$ Weight of dish + sample after drying

\section{2) Crude protein determination}

The micro Kjeldahl method described by [24] was used. Two grams (2 g) of each sample was mixed with $10 \mathrm{ml}$ of concentrated $\mathrm{H}_{2} \mathrm{SO}_{4}$ in a heating tube. One tablet of selenium catalyst was added to the tube and the mixture heated inside a fume cupboard until a colourless solution appeared. The resultant digest was transferred into distilled water, 10 millimeter portion of which was mixed with equal volume of $45 \% \mathrm{NaOH}$ solution was poured into a Kjeldahl distillation apparatus. The mixture was distilled and the distillate collected into $4 \%$ boric acid solution containing 3 drops of methyl red indicator. A total of $50 \mathrm{ml}$ distillate was collected and titrated against $0.02 \mathrm{~N}$ of $\mathrm{HCl}$. The samples were done in triplicate and the average value taken. The Nitrogen content was calculated and multiplied with 6.25 (used as a conversion factor) to obtain the crude protein content.

$$
\text { Percentage Nitrogen }=[(100 \times N \times 14 \times V F) T] \div 100 \times V a
$$


where

$$
\begin{aligned}
& N=\text { Normality of the titrate }(0.1 \mathrm{~N}) \\
& V F=\text { Total volume of the digest }=100 \mathrm{ml} \\
& T=\text { Titre Value } \\
& V a=\text { Aliquot Volume distilled }
\end{aligned}
$$

\section{3) Determination of crude fat content}

Total crude fat was determined using the Soxhlet method [25]. Two grams (2 g) of sample were collected in a thimble and was covered tightly with a cotton wool. Later the thimble containing the samples was placed in an empty metallic beaker containing $40 \mathrm{ml}$ of extraction solvent (Petroleum Ether PE). The metallic beaker containing the thimble and PE were later fixed to soxtec equipment (TECATOR 3516, Sweden). Fat extraction was done by boiling the samples for about an hour and rinsing for 30 minutes. The solvent was distilled off and the resultant fat was dried in a hot oven with a fan (GALLENKAMP SG93/08/850 size $2, \mathrm{UK}$ ) at $100^{\circ} \mathrm{C}$ for about 30 minutes to remove the remaining solvent and was later cooled in a dessicator. The oil collected and the beaker was weighed after cooling. Percentage fat content was determined using the following formula:

$$
\% \text { Fat content }=[(W 3-W 2) \div W 1] \times 100
$$

where $W 1=$ weight of sample, $W 2=$ weight of empty beaker, $W 3=$ weight of beaker + fat.

\section{4) Determination of ash content}

Ash content was determined according to [24]. The crucibles for ashing were properly washed and dried in a hot air oven and allowed to cool in desiccators. The crucibles were weighed and recorded as $W 1$. Flour sample (1 gram) was weighed into the crucible. The sample was then ashed at $550^{\circ} \mathrm{C}$ for six hours (Muffle furnace, CWF 13/5 SN = 20 - 503,092, England). The ashing was completed when there was no black speck in the ash. After ashing, the crucibles containing the ash were transferred to desiccators to cool after which the weight was taken. The difference in weight between the empty crucible and the crucible plus the ash was then calculated as ash content. The percentage ash was calculated as follows

$$
\% \text { Ash content }=[(W 3-W 1) \div W 2] \times 100
$$

where $W 1=$ weight of empty crucible, $W 2=$ weight of sample, $W_{3}=$ weight of crucible + ash.

\section{5) Determination of crude fibre}

Crude fibre was determined according to the method of [24]. Two grams (2 g) of sample was mixed into $200 \mathrm{ml}$ of $1.25 \%$ of $\mathrm{H}_{2} \mathrm{SO}_{4}$ in a $600 \mathrm{ml}$ beaker and boiled for 30 minutes. The content was then poured into a Buchner funnel covered with muslin cloth and held with elastic band. This was allowed to filter and residue was then added to $200 \mathrm{ml}$ of boiled $\mathrm{NaOH}$ in another $600 \mathrm{ml}$ beaker and boiling was continued for 30 minutes. It was further transferred to the Buchner funnel and filtered; then finally the material obtained was washed with alcohol. The residue obtained was placed in a clean dry pre weighed crucible and dried in 
a moisture extraction hot oven with fan (GALLENKAMP SG93/08/850 size 2, $\mathrm{UK})$ at $100^{\circ} \mathrm{C}$ to a constant weight. The dried crucible was removed, cooled and weighed to get weight of sample after oven drying. The dried sample was then ashed at $550^{\circ} \mathrm{C}$ for six hours (Muffle furnace, CWF 13/5 SN = $20-503,092$, England). The ashing was completed when there was no black speck in the ash. After ashing, it was cooled in the dessicators and weighed to get weight of ash. Then, difference of weight (i.e. loss in ignition) was recorded as crucible fibre and expressed in percentage.

$$
\% \text { Crude fibre }=[(W 1-W 2) \div W 3] \times 100
$$

where: $W 1=$ weight of sample after oven drying (before incineration), $W 2=$ weight of sample after incineration, $W 3=$ weight of original sample.

\section{6) Determination of dietary fibre}

The dietary fibre content of the instant flour was determined according to the method described by [26]. For each sample, 0.5 gram of flour ( $W 1)$ was weighed into a $600 \mathrm{ml}$ flask, into which $50 \mathrm{ml}$ of acid detergent fibre was added and the mixture boiled for 1 hour. The mixture was filtered over Buchner funnel connected to a vacuum pump and transferred to a pre weighed sinter glass (W2). The sinter glass crucibles were taken to hot oven with fan (GALLENKAMP SG93/08/850 size 2, UK) maintained at $100^{\circ} \mathrm{C}$ for 45 minutes to drive off the moisture. After drying, the crucible containing the sample was cooled and weighed $\left(W_{3}\right)$. Dietary fibre was obtained as the difference in weight of the empty sinter-glass and that after removal from the oven. The percentage dietary fibre content was calculated as follows

$$
\% \text { Dietary fibre }=[(W 3-W 2) \div W 1] \times 100
$$

where $W 1=$ weight of sample, $W 2=$ weight of empty crucible, $W 3=$ weight of crucible + sample after oven drying.

\section{7) Determination of carbohydrate content}

The nitrogen free method described by [24] was used. The carbohydrate was calculated as weight difference between 100 and the summation of the percentage of other proximate parameters as Nitrogen Free Extract (NFE) percentage carbohydrate

$$
(\mathrm{NFE}) .=100-\%(m+p+F 1+A+F 2)
$$

where $m=$ moisture, $p=$ protein, $F 1=$ crude Fat, $A=$ ash, $F 2=$ crude fibre.

\section{8) Determination of energy content}

Energy was estimated using the Atwater factors: 4, 9 and 4 for protein, fat and carbohydrate; respectively [27]. The percent energy content for the formulations was calculated by multiplying the values obtained for crude protein and carbohydrate contents with 4 respectively while crude fat was multiplied with 9, followed by summation of the values derived.

\subsubsection{Vitamin A and Mineral Analysis}

\section{1) Determination of vitamin A content}

Vitamin A content was analyzed according to the method developed by [28] 
following the guideline of [29]. One gram $(1 \mathrm{~g})$ of the flour was weighed and transferred to a mortar, homogenized with $50 \mathrm{ml}$ of cold acetone to extract beta carotene. The filtrate containing beta carotene and acetone was poured into a 50 $\mathrm{ml}$ volumetric flask through funnel with glass wool (to prevent sediments from entering). The remaining residue was washed several times with acetone until it became colourless and the $50 \mathrm{ml}$ volumetric flask was topped up to the mark with acetone. Petroleum ether PE $(40 \mathrm{ml})$ was poured into $500 \mathrm{ml}$ separating funnel with Teflon stop-cock and the carotenoid filtrate containing the acetone was slowly added. The partitioning of the aqueous and organic phase (containing the carotenoids) was observed after addition of filtrate. Distilled water (300 $\mathrm{ml}$ ) was slowly added (letting it flow along the walls of the separating funnel) to avoid the formation of emulsions. After the two phases were clearly formed, the lower phase (containing acetone and water) was discarded and the upper phase (mixtures of PE and carotenoids) was washed four times with $200 \mathrm{ml}$ distilled water to remove residual acetone.

The petroleum ether and carotenoid phase was collected into a $50 \mathrm{ml}$ volumetric flask. It was passed through a small funnel containing 15 grams of anhydrous sodium sulphate to remove residual water from separating funnel. A piece of glass wool was plugged on the funnel to hold the anhydrous sodium sulphate in place. The separating funnel was washed with $\mathrm{PE}$ and the washings collected in the $50 \mathrm{ml}$ volumetric flask via the funnel which was topped up to the mark with PE. The total carotenoid extracted was determined by taking the absorbance at $450 \mathrm{~nm}$ using the absorbance spectrophotometer (GENESYS 10UV 2G2J144001 Thermo electron co-operation, USA).

Total carotenoid content was calculated as:

$$
\text { Total carotenoid content }(\mu \mathrm{g} / \mathrm{g})=\left[\left(A \times V \times 10^{4}\right) / A_{\mathrm{lcm}}^{1 \%} \times W\right]
$$

where

$A=$ Absorbance, $V=$ Volume of extract, $A_{\mathrm{lcm}}^{1 \%}=$ Absorption coefficient of beta carotene in petroleum ether (2592), $W=$ Weight (g) of sample.

Vitamin A $(\mu \mathrm{g} / 100 \mathrm{~g})$ RAE was calculated as:

$$
\text { Vitamin A }(\mu \mathrm{g} / 100 \mathrm{~g}) \mathrm{RAE}=[\text { Total carotenoids }(\mu \mathrm{g} / 100 \mathrm{~g}) / 12]
$$

\section{2) Determination of total iron and zinc content}

Iron and zinc content was determined following laboratory methods for soil and plant analysis [30]. The flour quantity of 0.3 gram ( $w$ ) was weighed into a clean and dry digestion tube and $10 \mathrm{ml}$ of digestion mixture was added. The mixture and blanks were digested using a heating block until the solution turned colourless at $330^{\circ} \mathrm{C}$. Working solutions of iron or zinc $(50 \mathrm{ppm}$ Fe or $50 \mathrm{ppm}$ $\mathrm{Zn})$ were prepared from iron or zinc stock solutions (1000 ppm Fe or $1000 \mathrm{ppm}$ $\mathrm{Zn})$. Standard solutions of Fe were made by adding $0.8 \mathrm{Mol} / \mathrm{litre}$ of $\mathrm{H}_{2} \mathrm{SO}_{4}$ to 0 , 2.0, 4.0, 8.0, 12.0, 16.0 and $20 \mathrm{ml}$ of $50 \mathrm{ppm}$ Fe to make 0, 1, 2, 4, 6, 8, $10 \mathrm{ppm} \mathrm{Fe.}$ Standard solutions of zinc were made by adding $0.8 \mathrm{~mol} /$ litre of $\mathrm{H}_{2} \mathrm{SO}_{4}$ to $0,1.0$, 2.0, 4.0, 8.0 and $10 \mathrm{ml}$ of $50 \mathrm{ppm} \mathrm{Zn}$ to make $0,0.5,1,2,4$ and $5 \mathrm{ppm} \mathrm{Zn}$. 
Standard series and suitably diluted sample and blank were aspirated into atomic absorption spectrophotometer (Savant AA 2009, GBC scientific equipment Austria). Iron was measured at the wavelength $248.3 \mathrm{~nm}$, slit $0.2 \mathrm{~nm}$ and zinc was measured at $213.9 \mathrm{~nm}$, slit $0.7 \mathrm{~nm}$ using lean blue flame. A calibration curve of absorbance readings of the standard series against concentrations of the standard solutions was plotted separately for $\mathrm{Fe}$ and $\mathrm{Zn}$ to get the slope. The concentration of iron or zinc in the solution (denoted as a) and concentration of iron or zinc in the mean of blank (denoted as $b$ ) were all derived from the plotted graph. The actual concentrations of $\mathrm{Fe}$ and $\mathrm{Zn}$ in the dried samples were calculated as:

Concentration of Iron or Zinc $\left(\mathrm{mgkg}^{-1}\right)=[(a-b) \times v \times f \times 1000 \div(1000 \times w)]$

where $a=$ Concentrations of Iron or Zinc in the solution, $b=$ Concentrations of Iron or Zinc in the mean of the blanks, $v=$ Final volume of the digest, $w=$ Weight of the sample, $f=$ Dilution factor.

\section{3) Determination of iron and zinc extractability in OSG and RSG flours}

Iron and zinc extractability was determined using HCl-extractability method [31]. The minerals in 1 gram of the samples were extracted with $10 \mathrm{ml}$ of $0.03 \mathrm{~N}$ $\mathrm{HCl}$ by shaking in a water bath at $37^{\circ} \mathrm{C}$ for 3 hours. The clear filtrate obtained after filtration with Whatman \# 42 filter paper was oven dried at $100^{\circ} \mathrm{C}$ and wet acid digested. The amounts of the $\mathrm{HCl}$-extractable zinc and iron in the digested samples was determined with the same method described earlier for determination of total mineral content:

Mineral extractability $\%=[($ Mineral extractable in $0.03 \mathrm{~N} \mathrm{HCl} \div$ Total min eral $) \times 100]$

\subsubsection{Determination of Nutrient Densities of Vegetable Enriched Products and Commercial Products}

The nutrient densities were calculated for orange fleshed sweet potato composite (OSG) porridge and red amaranth composite (RSG) soup and were compared to the nutrient densities of the commonly consumed maize porridge and commercial wheat flour composite soup. The nutrient densities were calculated based on the $16 \%$ flour rate for preparing porridge from OFSP composite (OSG) and $10 \%$ flour rate for preparing soup from red amaranth composite (RSG) as these flour rates yielded different viscosity results. The general recommended viscosity of porridge for children should be in the range of $2500 \mathrm{cP}$ to $3000 \mathrm{cP}$ [18] [19] which influenced the flour rate for OFSP composite. But while there is still currently no general recommended viscosity of soups for children, it is expected that the viscosity is slightly lower than that of porridge for easy flow and consumption. The nutrient density of the commercial wheat flour composite soup was calculated using 6\% FR (as preparation FR recommended by the manufacturer). For effective comparison with commercial wheat flour composite soup, nutrient density of red amaranth composite soup (RSG) was also calculated at $6 \%$ FR and used for comparison. The nutrient density of commonly consumed maize porridge was equally determined from the result of the flour rate generated. The flour rates of the porridges and soups were used to calculate energy, 
protein, vitamin A and mineral densities of the porridges and soups in accordance with their respective nutrient contents. The nutrient content derived for each porridge or soup flours was multiplied by its flour rate divided by $100 . \mathrm{Nu}-$ trient density was calculated in wet basis edible portions.

\subsubsection{Estimated Contribution (\%) of the Products to the RDA of School Age Children (5 to 13 Years)}

The contribution of the product to nutrient intakes of children was achieved based on the results of the nutrient densities of the porridges and soups, age group serving portions alongside the RDA of children aged 5 to 13 years. For chapattis, the contribution was based on their nutrient content and age group serving portions alongside their RDA. Since a young child (below 5 years) can consume up to $300 \mathrm{ml}$ or more of porridge [32], it was assumed in this study that school age children (5 to 13 years) can consume up to $500 \mathrm{ml}$ of porridge and soup since there was limited or no publication on appropriate quantity of porridge and soup for school age children.

\subsection{Data Analysis}

Sensory evaluation data was analyzed using SPSS version 16; Means of two samples were compared using the T-test and separated using the least significant difference test (LSD) at $5 \%$ level of significance $(\mathrm{P}<0.05)$. Genstat software was used to analyze the nutrient and pasting data. Pasting properties was done in duplicate while other analyses were done in triplicate and average values taken.

\section{Results and Discussion}

\subsection{Food Formulations}

Orange fleshed sweet potato and red amaranth vegetables incorporated separately $(10 \%)$ into soybean $(40 \%)$ and grain amaranth $(50 \%)$ exhibited varying vitamin A, iron, zinc, protein and energy contents (Table 1).

The Recommended Dietary Allowance for both female and male aged 5 to 13 years ranges from $8-10 \mathrm{mg}$ for iron, $5-8 \mathrm{mg}$ for zinc, $400-600 \mu \mathrm{g} / \mathrm{d}$ for vitamin A, 19 - 34 grams for protein and 1300 - $1700 \mathrm{Kcal}$ for energy [33]. These formulations were expected to contribute to part of their daily requirements.

\subsection{Test for Acceptability of Vegetable Enriched Products Compared to Commercial Products $(n=70)$}

\subsubsection{Viscosity of the Vegetable Enriched Porridge and Soup and that of Commercial Products}

The maize porridge attained recommended drinkable viscosity $(2500 \mathrm{cP}$ to 3000 cP) for children at 7\% FR (2679 cP), while OFSP attained the same viscosity range at a higher FR (16\%) with viscosity of $2892 \mathrm{cP}$. This implied that commonly used sole maize porridges are too viscous and can only accommodate lower flour rate, thereby limiting maize porridges of their nutrients amidst the little it has. The viscosity of red amaranth composite soup, prepared and served at $10 \% \mathrm{FR}$ was $1644 \mathrm{cP}$; while that of commercial wheat flour based composite 
soup served at $6 \% \mathrm{FR}$ (following the manufacturer's specifications) was $524 \mathrm{cP}$.

\subsubsection{Test of Consumer Acceptability for Porridges}

Sensory characteristics of a food are key factors for determination of nutrient intake of children because they can influence consumption. The sensory acceptability scores of porridges for all the attributes ranged from 3.4 for maize porridge to 4.6 for OFSP composite porridge (Table 6). For all the attributes including the overall acceptance with the exception of colour, porridge from OFSP composite scored significantly higher $(\mathrm{P}<0.05)$ than porridge from maize flour. Similar results were also observed by [34] for composite porridge prepared with $10 \%$ OFSP compared with $100 \%$ maize flour porridge.

The higher overall acceptance of 4.5 for OSG porridge compared to 3.7 for maize porridge showed that OSG porridge was better/much liked and accepted than commonly consumed sole maize porridge usually served to school children. This might be due to the fact that OSG porridge contains three food materials: OFSP, soybean and grain amaranth which also depicts that composite nature of foods can lead to enhanced acceptability.

\subsubsection{Test of Acceptability for the Snacks-Chapattis}

The acceptability scores of chapattis ranged from 3.6 for $100 \%$ wheat flour chapattis to 4.5 for chapattis made from 30:70 OFSP composite flour to wheat flour; respectively (Table 7). For all the attributes determined except taste, chapatti from 30:70 OFSP composite to wheat flour scored significantly higher $(\mathrm{P}<0.05)$ than chapatti made from $100 \%$ wheat flour.

Similar to porridge, the higher overall acceptance of OSG chapattis 4.5 compared to 4.1 for $100 \%$ wheat flour chapattis suggests that when OSG chapattis is served as a mid-morning snack to school children, its uptake as a substitute to the regular $100 \%$ wheat flour chapattis could be high. Similar scores of acceptability of cake made with OFSP were observed by [35].

\subsubsection{Test of Acceptability for Soups}

The acceptability scores of soups ranged from 3.4 for commercial wheat composite soup to 4.0 for red amaranth composite soup (Table 8). Red amaranth

Table 6. Sensory acceptability of porridge from OFSP composite flour (OSG) compared to maize flour porridge.

\begin{tabular}{ccc}
\hline Acceptability scores & & \\
\hline Attributes & OFSP composite (OSG) porridge & Maize porridge \\
\hline Colour & $4.2 \pm 1.2^{\mathrm{a}}$ & $3.8 \pm 1.1^{\mathrm{a}}$ \\
Flavour & $4.6 \pm 0.9^{\mathrm{a}}$ & $3.4 \pm 1.3^{\mathrm{b}}$ \\
Taste & $4.3 \pm 0.9^{\mathrm{a}}$ & $3.6 \pm 1.4^{\mathrm{b}}$ \\
Overall acceptance & $4.5 \pm 1.0^{\mathrm{a}}$ & $3.7 \pm 1.3^{\mathrm{b}}$ \\
\hline
\end{tabular}

Values show mean $\pm S D$ ( $n=70$ school children aged 5 to 13 years). Figures in a row with the same superscript are not significantly different $(P \geq 0.05)$. A 5 -point hedonic scale with the following anchors was used: 1-Dislike extremely, 2-Dislike moderately, 3-Neither like nor dislike, 4-like moderately, 5-like extremely. 
Table 7. Sensory acceptability of chapattis from 30:70 OFSP composite (OSG) and wheat flour respectively compared to chapattis from $100 \%$ refined wheat flour.

\begin{tabular}{ccc}
\hline Acceptability scores & & \\
\hline Attributes & $\mathbf{7 0 :}$ 30 Wheat flour and OFSP composite (OSG) & 100\% refined wheat flour \\
\hline Colour & $4.2 \pm 0.7^{\mathrm{a}}$ & $3.6 \pm 1.1^{\mathrm{b}}$ \\
Flavour & $4.4 \pm 0.9^{\mathrm{a}}$ & $3.7 \pm 1.2^{\mathrm{b}}$ \\
Taste & $3.9 \pm 0.9^{\mathrm{a}}$ & $4.0 \pm 1.2^{\mathrm{a}}$ \\
Overall acceptance & $4.5 \pm 0.6^{\mathrm{a}}$ & $4.1 \pm 0.9^{\mathrm{b}}$ \\
\hline
\end{tabular}

Values show mean $\pm S D$ ( $n=70$ school children aged 5 to 13 years). Figures in a row with the same superscript are not significantly different $(\mathrm{P} \geq 0.05)$. A 5-point hedonic scale with the following anchors was used: 1-Dislike extremely, 2-Dislike moderately, 3-Neither like nor dislike, 4-like moderately, 5-like extremely.

Table 8. Sensory acceptability of red amaranth composite soup (RSG) compared to a commercial wheat flour-based composite soup.

\begin{tabular}{ccc}
\hline Acceptability scores & & \\
\hline Attributes & Red amaranth composite soup & Wheat flour composite soup \\
\hline Colour & $3.8 \pm 1.3^{\mathrm{a}}$ & $3.4 \pm 1.5^{\mathrm{a}}$ \\
Flavour & $3.7 \pm 1.4^{\mathrm{a}}$ & $3.4 \pm 1.5^{\mathrm{a}}$ \\
Taste & $3.8 \pm 0.9^{\mathrm{a}}$ & $3.4 \pm 1.5^{\mathrm{a}}$ \\
Overall acceptance & $4.0 \pm 1.0^{\mathrm{a}}$ & $3.5 \pm 1.2^{\mathrm{b}}$ \\
\hline
\end{tabular}

Values show mean $\pm S D(n=70$ school children aged 5 to 13 years). Figures in a row with the same superscript are not significantly different $(\mathrm{P} \geq 0.05)$. A 5-point hedonic scale with the following anchors was used: 1-Dislike extremely, 2-Dislike moderately, 3-Neither like nor dislike, 4-like moderately, 5-like extremely.

composite soup scored higher than wheat flour composite soup for all attributes but there was no significant difference $(\mathrm{P}>0.05)$ for colour, flavor and taste. The overall acceptance of red amaranth composite soup was 4.0 which was significantly different $(\mathrm{P}<0.05)$ from 3.5 for wheat flour composite soup.

The higher overall acceptance score of 4.0 for red amaranth composite soup (RSG) compared to 3.5 for commercial wheat flour composite soup shows that when this product is eventually introduced into school feeding with accompany staple for lunch and/or dinner, its consumption can be assured. The acceptability result was similar to that of peanut sauce prepared with amaranth leaves and peanut [17] and pasta prepared with wheat flour and amaranth leaves [36]. The higher acceptability ratings for these vegetable enriched products against the commercial foods might probably be due to complementation for taste and nutrient contents by the composite flours against sole nature of most commercial foods.

\subsection{Comparison of the Pasting Properties of Vegetable Enriched Porridge and Soup Flours with that of Commercial Porridge and Soup Flours Respectively}

The pasting properties of orange fleshed sweet potato composite flour OSG and Maize flour are shown in Table 9 and Figure 1; while that of soup from red 
Table 9. Pasting properties of OFSP composite flour (OSG) and maize flour*.

\begin{tabular}{ccc}
\hline Pasting property & OSG & Maize flour \\
\hline Peak Viscosity (cP) & $490.0 \pm 6.4^{\mathrm{a}}$ & $3291 \pm 90.5^{\mathrm{b}}$ \\
Trough viscosity (cP) & $431.0 \pm 4.2^{\mathrm{a}}$ & $2246 \pm 204.4^{\mathrm{a}}$ \\
Breakdown viscosity (cP) & $59.5 \pm 2.1^{\mathrm{a}}$ & $1044.5 \pm 113.8^{\mathrm{a}}$ \\
Final viscosity (cP) & $618.0 \pm 9.2^{\mathrm{a}}$ & $6289 \pm 7.1^{\mathrm{b}}$ \\
Set back viscosity (cP) & $186.0 \pm 4.9^{\mathrm{a}}$ & $4042 \pm 211.4^{\mathrm{b}}$ \\
Peak time (minutes) & $6.1 \pm 0.0^{\mathrm{a}}$ & $5.5 \pm 0.0^{\mathrm{b}}$ \\
Pasting temperature $\left({ }^{\circ} \mathrm{C}\right)$ & $88.5 \pm 1.7^{\mathrm{a}}$ & $77.85 \pm 0.6^{\mathrm{b}}$ \\
\hline
\end{tabular}

${ }^{*}$ Values presented as mean $\pm S D(n=2)$. Figures in a row with the same superscript are not significantly different $(\mathrm{P} \geq 0.05)$.

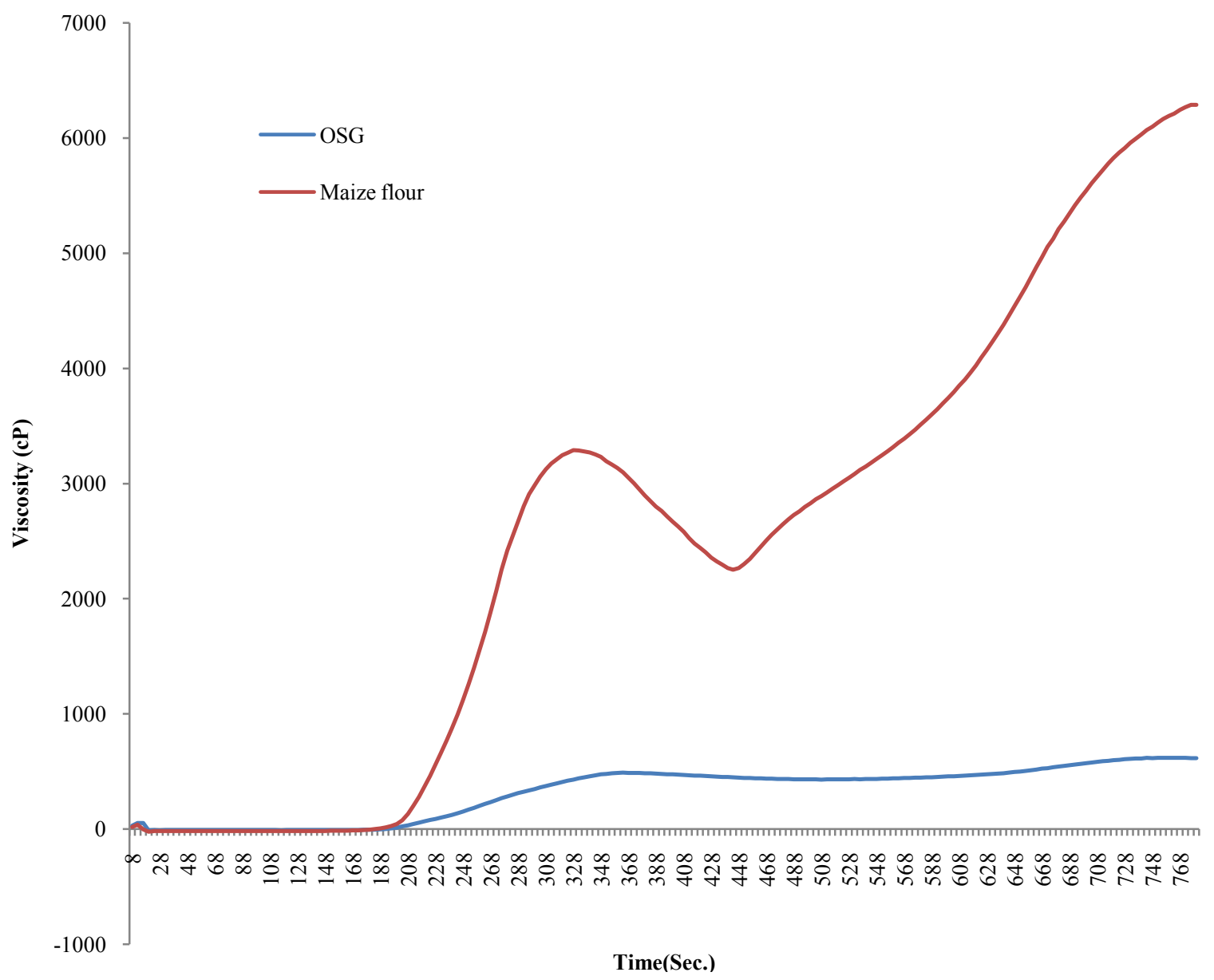

Figure 1. Rapid visco analyzer (RVA) profiles of the OFSP composite flour (OSG) and maize flour $(n=2)$.

amaranth composite flour RSG and commercial wheat composite soup flour are shown in Table 10 and Figure 2.

From Table 9, peak viscosity, final viscosity, setback viscosity and peak time of OSG flour was significantly lower $(\mathrm{P}<0.05)$ than that of maize flour, and OSG had significantly higher pasting temperature $(\mathrm{P}<0.05)$ than the maize flour. The final viscosity values were $618 \mathrm{cP}$ and $6289 \mathrm{cP}$ for OSG and maize flour respectively. 
Table 10. Pasting properties of soup flours from red amaranth composite and commercial wheat flour composite*.

\begin{tabular}{ccc}
\hline Pasting property & Red amaranth composite & Wheat composite \\
\hline Peak Viscosity $(\mathrm{cP})$ & $474.0 \pm 15.6^{\mathrm{a}}$ & $883.5 \pm 5.0^{\mathrm{b}}$ \\
Trough viscosity $(\mathrm{cP})$ & $452.9 \pm 14.9^{\mathrm{a}}$ & $621.5 \pm 7.8^{\mathrm{b}}$ \\
Breakdown viscosity (cP) & $21.5 \pm 0.7^{\mathrm{a}}$ & $262.0 \pm 2.0^{\mathrm{b}}$ \\
Final viscosity (cP) & $695.0 \pm 18.4^{\mathrm{a}}$ & $1461.0 \pm 2.8^{\mathrm{b}}$ \\
Set back viscosity (cP) & $242.5 \pm 3.5^{\mathrm{a}}$ & $839.5 \pm 5.0^{\mathrm{b}}$ \\
Peak time (minutes) & $6.2 \pm 0.1^{\mathrm{a}}$ & $6.0 \pm 0.0^{\mathrm{a}}$ \\
Pasting temperature $\left({ }^{\circ} \mathrm{C}\right)$ & $82.4 \pm 0.0^{\mathrm{a}}$ & $93.2 \pm 0.5^{\mathrm{b}}$ \\
\hline
\end{tabular}

${ }^{*}$ Values show mean $\pm S D(n=2)$. Figures in a row with the same superscript are not significantly different $(\mathrm{P} \geq 0.05)$.

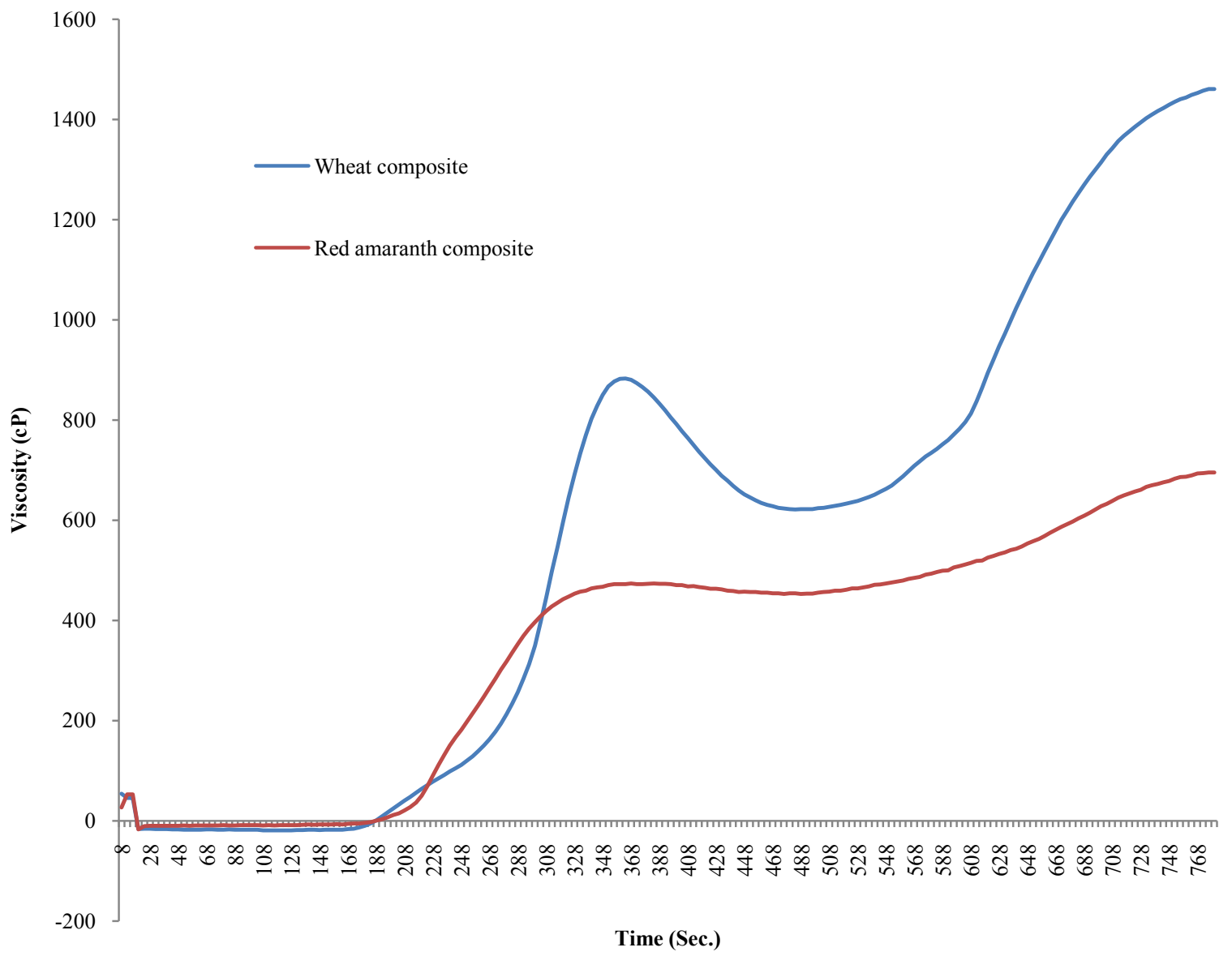

Figure 2. Rapid visco analyzer (RVA) profiles of red amaranth composite soup flour and commercial wheat composite soup flour $(\mathrm{n}=2)$.

The low viscosities (peak, trough, breakdown, setback and final viscosity), high peak time and pasting temperature exhibited by OSG suggested that they are less viscous and more heat stable for making porridges than maize flour which had high; peak, breakdown, setback and final viscosities. The high viscosities of maize porridge may probably be due to high starch content of maize flour (approximately $66 \mathrm{~g}$ per $100 \mathrm{~g}$ of flour; [7]) compared to $44 \mathrm{~g}$ per $100 \mathrm{~g}$ of OSG 
flour (derived from concept 4 software). Such high viscosity during cooking can lead to further addition of excess water to the porridge by mothers/caregivers so as to reduce the bulkiness to a drinkable consistency, but this equally leads to further dilution of the nutrients in it amidst the little it had. That is the reason why sole cereal flours with very high viscosity and low nutrient contents cannot be suitable for school children's porridges that require high nutrient dense foods at their stage.

From Table 10, peak, trough, breakdown, setback and final viscosities of red amaranth composite soup flour were significantly lower $(\mathrm{P}<0.05)$ than commercial wheat composite soup flour but conversely, wheat composite soup flour had a higher pasting temperature than red amaranth composite soup flour and this difference was significant $(\mathrm{P}<0.05)$. There was no significant difference $(\mathrm{P}>0.05)$ between the two flours for the peak time. The final viscosity values were $695 \mathrm{cP}$ and $1461 \mathrm{cP}$ for red amaranth composite soup flour and commercial wheat composite soup flour respectively. Table 10 and Figure 2 indicate that red amaranth composite soup flour presents better pasting characteristics than commercial wheat composite soup flour with the former having a higher peak time, lower: peak, trough, breakdown, final and setback viscosities than the latter. The result also suggests that a higher flour rate can be used to produce RSG soup than that used for wheat composite soup. This implies that more nutrient and energy dense soups can be prepared from RSG soup than from commercial wheat based soup.

\subsection{Proximate Composition of OFSP Composite (OSG) and Red Amaranth Composite (RSG) Flours}

From Table 11, RSG had high ash, crude fibre and protein content while OSG had high carbohydrate, crude fat, moisture and energy. There was a significant difference $(\mathrm{P}<0.05)$ between the two formulations for ash content and protein content, crude fat, carbohydrate and energy of which RSG was higher in ash and protein contents while OSG was higher in crude fat, carbohydrate and energy.

The ash content is an indicator of the mineral content in flour. The ash content of red amaranth composite was higher $(\mathrm{P}<0.05)$ than that of OFSP composite. This indicates that red amaranth composite contains more of minerals. The protein content of the both formulations was quite higher than that predicted by concept 4 software (Table 1), probably due to geographical variations in the raw materials used. The moisture content of both samples was not more than $10 \%$ as recommended by CODEX [37], which signifies shelf stability (i.e. can be safely stored at room or ambient temperature for a usefully long shelf life).

\subsection{Total Carotenoid and Vitamin A Content of the Most Acceptable Flour Formulations}

Beta carotene is the most important provitamin-A carotenoid found in plant foods which are converted to its active form vitamin A in the body. Vitamin A helps in vision support, strengthens the immune system, for growth and increases intellectual ability and cognition in children [38]. The total carotenoids 
Table 11. Nutrient contents and mineral extractabilities of OFSP composite (OSG) and red amaranth composite (RSG) flours (wet weight basis)*.

\begin{tabular}{ccc}
\hline Proximate compositions & OSG & RSG \\
\hline Ash (\%) & $2.9 \pm 0.1^{\mathrm{a}}$ & $4.3 \pm 0.1^{\mathrm{b}}$ \\
Crude fibre (\%) & $3.4 \pm 0.4^{\mathrm{a}}$ & $3.9 \pm 0.2^{\mathrm{a}}$ \\
Moisture (\%) & $8.0 \pm 0.0^{\mathrm{a}}$ & $7.9 \pm 0.1^{\mathrm{a}}$ \\
Protein (\%) & $27.9 \pm 0.6^{\mathrm{a}}$ & $31.2 \pm 0.1^{\mathrm{b}}$ \\
Crude Fat (\%) & $13.8 \pm 0.2^{\mathrm{a}}$ & $13.4 \pm 0.2^{\mathrm{b}}$ \\
Carbohydrate (\%) & $44.3 \pm 0.5^{\mathrm{a}}$ & $39.4 \pm 0.2^{\mathrm{b}}$ \\
Energy (Kcal) & $413.0 \pm 1.8^{\mathrm{a}}$ & $402.5 \pm 1.0^{\mathrm{b}}$ \\
\hline Total carotenoid and vitamin $\mathrm{A} \mathrm{content \textrm {s } ^ { + }}$ & \\
\hline Total carotenoids ( $\mu \mathrm{g} / 100 \mathrm{~g})$ & $2327 \pm 17.5^{\mathrm{a}}$ & $4812 \pm 39.8^{\mathrm{b}}$ \\
Vitamin A ( $\mu \mathrm{g} / 100 \mathrm{~g}$ RAE) & $194.0 \pm 1.5^{\mathrm{a}}$ & $401.0 \pm 3.3^{\mathrm{b}}$ \\
\hline Mineral contents and extractabilities & \\
\hline Total Fe (mg/100 g) & $6.5 \pm 0.1^{\mathrm{a}}$ & $8.8 \pm 0.2^{\mathrm{b}}$ \\
Extractable Fe (\%) & $40.6 \pm 1.2^{\mathrm{a}}$ & $35.9 \pm 0.9^{\mathrm{b}}$ \\
Total Zn (mg/100 g) & $3.6 \pm 0.1^{\mathrm{a}}$ & $4.1 \pm 0.0^{\mathrm{b}}$ \\
Extractable Zn (\%) & $56.5 \pm 1.1^{\mathrm{a}}$ & $40.7 \pm 0.6^{\mathrm{b}}$ \\
\hline
\end{tabular}

${ }^{*}$ Values represent mean \pm SD $(n=3)$. Figures in a row with the same superscript are not significantly different $(\mathrm{P} \geq 0.05) .{ }^{+} 1 \mathrm{RAE}=1 \mu \mathrm{g}$ retinol, $12 \mu \mathrm{g} \beta$-carotene. OSG $=10 \%$ OFSP, $40 \%$ soybean and $50 \%$ grain amaranth, $\mathrm{RSG}=10 \%$ red amaranth leaves, $40 \%$ soybean and $50 \%$ grain amaranth.

and vitamin A contents of both formulations were significantly different $(\mathrm{P}<$ 0.05) (Table 11) with red amaranth composite (RSG) having a higher content of total carotenoid $(4812 \mu \mathrm{g} / 100 \mathrm{~g})$ and vitamin A (401 $\mu \mathrm{g} / 100 \mathrm{~g}$ RAE) than OFSP composite (OSG) which had total carotenoid of $2327 \mu \mathrm{g} / 100 \mathrm{~g}$; and vitamin A content of $193.95 \mu \mathrm{g} / 100 \mathrm{~g}$ RAE. The beta carotene content of OFSP composite (OSG) were similar to results obtained by [39] while that of red amaranth composite (RSG) were similar to the values reported by [40] for "mathri" prepared with Amaranthus panicualtus leaves. The vitamin A content of both formulations were similar but higher than the values predicted by concept 4 software $(192 \mu \mathrm{g} / 100 \mathrm{~g}$ RAE for OSG flour and $376 \mu \mathrm{g} / 100 \mathrm{~g}$ RAE for RSG flour) as shown in Table 1. The higher levels of vitamin A of OSG and RSG than those values predicted were probably due to geographical variations in the raw materials used.

\subsection{Mineral Content and Extractabilities of the Most Acceptable Formulations}

The total iron content of red amaranth composite (RSG) was $8.8 \mathrm{mg} / 100 \mathrm{~g}$ and was significantly higher $(\mathrm{P}<0.05)$ than the $6.5 \mathrm{mg} / 100 \mathrm{~g}$ content contained in OFSP composite (OSG) (Table 11). Conversely, OSG had a higher $(\mathrm{P}<0.05)$ extractable iron score (40.6\%) than RSG (35.9\%). Similarly, red amaranth composite RSG also had higher total zinc content $(4.1 \mathrm{mg} / 100 \mathrm{~g})$ than OFSP composite OSG (3.6 mg/100 g) and RSG as well had lesser extractable zinc (40.7\%) 
compared to $56.5 \%$ of OSG.

The mineral content of both formulations were high, the lower extractabilities for both zinc and iron of red amaranth composite (RSG) were probably due to high content of fibre (3.9) in them than in OFSP composite (OSG) as shown in Table 11. High Fiber in foods hinders bioavailability of minerals such as zinc and iron [41] [42] [43]. The mineral content of the formulations was similar to that reported by [40]. The total iron content of both samples were higher than that predicted by concept 4 software ( $4.7 \mathrm{mg}$ for OSG and $7.1 \mathrm{mg}$ for RSG) as shown in Table 1. The zinc content of OFSP composite was also higher than that predicted by concept 4 software $(2.9 \mathrm{mg})$ as shown in Table 1 while zinc of RSG was slightly lower likewise may be as a result of geographical variations of the raw material used.

\subsection{Comparison of the Nutrient Content of Vegetable Enriched Flours, Their Products and Commercial Products}

From Table 12, orange fleshed sweet potato composite flour (OSG) had the highest energy, protein, dietary fibre, total fat, vitamin A, iron and zinc content than the commercial maize flour indicating it was more nutrient dense than maize flour. Red amaranth composite soup flour (RSG) was higher than commercial wheat composite soup flour in protein, dietary fibre, total fat, vitamin A, iron and zinc which also indicated that it was richer in key micronutrients than the latter. Chapatti made with $30 \%$ of OFSP composite (OSG) was also higher in protein, vitamin A, iron and zinc than chapatti made with $100 \%$ wheat flour but the latter was higher in energy, dietary fibre and fat content than the former. The vitamin A content of the chapattis made with $30 \%$ of OSG was similar to that derived by [16]. This results also indicated that OSG chapatti was more micronutrient dense while chapattis from $100 \%$ wheat flour was more energy dense than the OSG chapattis (Table 12).

\subsection{Nutrient Density of the Porridges and Soups Compared to Commercial Products}

The nutrient density for OFSP composite (OSG) porridge (at 16\% FR, $2892 \mathrm{cP}$ )

Table 12. Nutrient content of the vegetable enriched flours and product in comparison with commercial products per 100 grams (wet weight basis)*.

\begin{tabular}{ccccccc}
\hline Energy (Kcal) & $\mathbf{4 1 3 . 0}$ & $\mathbf{3 6 3}$ & $\mathbf{3 1 5}$ & $\mathbf{3 2 4}$ & $\mathbf{3 3 5 . 0}$ & $\mathbf{3 6 4 . 5}$ \\
\hline Protein (g) & 27.9 & 8.5 & 17.4 & 14.8 & 11.4 & 9.5 \\
Dietary fibre (g) & 13.1 & 6.4 & 7.9 & 0.6 & 4.1 & 6.2 \\
Total fat (g) & 13.8 & 3.7 & 4.0 & 3.2 & 12.7 & 15.3 \\
Vitamin A (RAE) & 194.0 & 0 & 564.1 & 25.1 & 172.4 & 61.1 \\
Iron (mg) & 6.5 & 1.5 & 10.5 & 7.2 & 5.6 & 3.0 \\
Zinc (mg) & 3.6 & 1.8 & 2.7 & 1.18 & 2.7 & 1.9 \\
\hline
\end{tabular}

${ }^{*}$ Maize flour values were based on nutrient database values of [7] Release 27 while other values were based on chemical analysis result from this study. ${ }^{*}$ Chapatti from $100 \%$ refined wheat flour. ${ }^{+}$RSG Soup Flour values were derived after addition of other dry soup ingredients (Table 2). 
was higher than that of maize porridge (at 7\% FR, $2679 \mathrm{cP}$ ) for all the parameters determined (Table 13). The nutrient density of soup from red amaranth composite (RSG) was higher at both $10 \%$ and $6 \%$ FR for protein, dietary fibre, vitamin $\mathrm{A}$, iron and zinc than wheat composite soup at $6 \%$ FR (Table 13). However, the commercial wheat composite soup was slightly higher in energy than red amaranth composite (RSG) soup at $6 \%$ FR. The results obtained for the nutrient density were in agreement with the results obtained for nutrient contents. The high nutrient density of OFSP composite (OSG) porridge and red amaranth composite (RSG) soup were probably due to higher nutrient contents, low viscosity and higher flour rate used than that of the commercial products. These results showed that the vegetable enriched products were both nutrient richer and denser than the commercial products for making porridges and soups.

\subsection{Estimated Contribution (\%) of the Vegetable Enriched Products to the RDA of Primary School Children Aged 5 to 13 Years}

The results for the contributions of the products to the RDA of school going children aged 5 to 8 years and 9 to 13 years are shown in Table 14. All the products contributed highly to the RDA of children aged 5 to 13 years [33]. When a child consumes $500 \mathrm{ml}$ of OSG porridge for breakfast, 2 chapattis (OSG) as mid-morning snack and a $500 \mathrm{ml}$ of RSG soup as lunch or dinner sauce, it will contribute to a certain percentage of their RDA as shown in Table 14. Results indicate that orange fleshed sweet potato composite porridge could contribute to; $38.8 \%$ of vitamin A, $60 \%$ of zinc, $50 \%$ of iron, $118.4 \%$ of protein and $25.4 \%$ of energy requirements of children aged 5 to 8 years; and thus $25.4 \%$ of vitamin $A$, $37.5 \%$ of zinc, $63 \%$ of iron, $66.2 \%$ of protein and $19.4 \%$ of energy to the RDA of children aged 9 to 13 years. Chapatti with 30\% of OFSP composite could contribute to; $60.3 \%$ of vitamin A, $75.6 \%$ of zinc, $78.4 \%$ of protein and $36.1 \%$ of energy to the RDA of children aged 5 to 8 years; translating to $40.2 \%$ of vitamin

Table 13. Comparison of nutrient density (per $100 \mathrm{ml}$ ) of the vegetable enriched porridge and soup to that of maize porridge and wheat-based composite soup.

\begin{tabular}{cccccc}
\hline Nutrient & $\begin{array}{c}\text { OSG } \\
\text { Porridge }\end{array}$ & $\begin{array}{c}\text { Maize } \\
\text { porridge* }\end{array}$ & $\begin{array}{c}\text { RSG Soup } \\
\text { at 10\% FR }\end{array}$ & $\begin{array}{c}\text { RSG Soup } \\
\text { at 6\% FR }\end{array}$ & $\begin{array}{c}\text { Wheat composite } \\
\text { at 6\% FR }\end{array}$ \\
\hline Energy (Kcal) & 66.1 & 25.4 & 31.5 & 18.9 & 19.4 \\
Protein (g) & 4.5 & 0.6 & 1.7 & 1.0 & 0.9 \\
Dietary fibre (g) & 2.1 & 0.4 & 0.8 & 0.5 & 0.0 \\
Total fat (g) & 2.2 & 0.3 & 0.4 & 0.2 & 0.2 \\
Vitamin A (RAE) & 31.0 & 0.0 & 56.4 & 33.8 & 1.5 \\
\hline Minerals (mg) & & & & & \\
\hline Iron & 1.0 & 0.1 & 1.1 & 0.6 & 0.4 \\
Zinc & 0.6 & 0.1 & 0.3 & 0.2 & 0.1 \\
\hline
\end{tabular}

$\mathrm{FR}=$ flour rate, ${ }^{*}$ Maize porridge values were based on nutrient database values of [7] Release 27 while other values are based on chemical analysis result from this study. 
Table 14. Estimated contribution (\%) of the most acceptable foods prepared from vegetable enriched composite flours to the RDA of the school children aged 5 to 8 and 9 to 13 years.

\begin{tabular}{|c|c|c|c|c|}
\hline \multirow[t]{2}{*}{ Products } & \multirow[t]{2}{*}{ Serving size } & \multicolumn{3}{|c|}{$\begin{array}{c}\text { Contribution } \\
\text { (one serving a day) to } 5-8 \text { years }\end{array}$} \\
\hline & & \multicolumn{3}{|c|}{ Vit. A Zn Fe Energy (Kcal)Protein } \\
\hline OFSP composite porridge (16\% FR) & $\begin{array}{c}500 \mathrm{ml} \\
\text { (1 tumpeco cup) }\end{array}$ & 38.860 .050 .0 & 25.4 & 118.4 \\
\hline Chapatti (with $30 \%$ of OSG)* & $\begin{array}{l}140 \text { grams } \\
\text { (2 pieces) }\end{array}$ & 60.375 .678 .4 & 36.1 & 84.0 \\
\hline Red amaranth composite soup ( $10 \%$ FR & $\begin{array}{c}500 \mathrm{ml} \\
\text { (1 tumpeco cup) }\end{array}$ & 70.530 .055 & 12.1 & 44.7 \\
\hline \multirow[t]{2}{*}{ Products } & Serving size & \multicolumn{3}{|c|}{$\begin{array}{c}\text { Contribution } \\
\text { (one serving a day) to } 9-13 \text { year }\end{array}$} \\
\hline & & \multicolumn{3}{|c|}{ Vit. A Zn Fe Energy (Kcal)Protein } \\
\hline OFSP composite porridge ( $16 \% \mathrm{FR})$ & $500 \mathrm{ml}$ (1 tumpeco cup) & 25.837 .563 .0 & 19.4 & 66.2 \\
\hline Chapatti (with $30 \%$ of OSG)* & 140 grams (2 pieces) & 40.247 .398 & 27.6 & 46.9 \\
\hline Red amaranth composite soup (10\% FR & $500 \mathrm{ml}$ (1 tumpeco cup) & 47.018 .868 .8 & 9.3 & 25 \\
\hline
\end{tabular}

A, $47.3 \%$ of zinc, $98 \%$ of iron, $46.9 \%$ of protein and $27.6 \%$ of energy to the RDA of children aged 9 to 13 years. The red amaranth composite soup could contribute to; $70.5 \%$ of vitamin A, $30 \%$ of zinc, $55 \%$ of iron, $44.7 \%$ of protein and $12.1 \%$ of energy to the RDA of children aged 5 to 8 years; translating to $47 \%$ of vitamin $A, 18.8 \%$ of zinc, $68.8 \%$ of iron, $25 \%$ of protein and $9.3 \%$ of energy to the RDA of children aged 9 to 13 years.

\section{Conclusions}

The study on sensory acceptability, nutritional quality and estimated contribution of vegetable enriched products to the nutrient requirements of school children aged 5 to 13 years was successfully achieved.

Products prepared either solely from the vegetable enriched composite flours (porridge), soup and snacks-chapattis (incorporating 30\% OFSP composite flour) were highly preferred by the school children and more nutrient dense than commercial foods. Based on their estimated contribution, the products can contribute significantly to the RDA of school children aged 5 to13 years.

In addition, OFSP composite flour and red amaranth composite flour have a higher potential for use as porridge and soup respectively than maize flour/ wheat based soup flour as the former had lower pasting viscosities than the latter signifying higher flour rate and nutrient density.

Based on the study findings, it can be concluded that highly nutritious and acceptable vegetable enriched products can be formulated with vegetables to contribute significantly to the RDA of school children aged 5 to 13 years for vitamin A, iron and zinc. Orange fleshed sweet potato composite can be recommended for use as porridge and as a partial substitute to wheat in preparation of 
chapattis while red amaranth composite can be recommended for soup. This approach is feasible and the products can be recommended in school feeding program to help ameliorate the problem of micronutrient deficiency among school children.

\section{Acknowledgements}

The authors would like to thank the various people who took part in this study. Special thanks to technicians who analyzed laboratory samples and the Food Technology Business Incubation Center (FTBIC) Makerere University, for the financial assistance that enabled this study to take place.

\section{References}

[1] FAO Food and Agricultural Organisation (2011) Combating Micronutrient Deficiencies: Food-Based Approaches. Edited by Brian Thompson and Leslie Amoroso, Published Jointly by CAB International and FAO, Rome.

[2] Ramakrishnan, U. (2002) Prevalence of Micronutrient Malnutrition Worldwide. Nutrition Reviews, 60, 46-52. https://doi.org/10.1301/00296640260130731

[3] Viteri, F.E. and Gonzalez, H. (2002) Adverse Outcomes of Poor Micronutrient Status in Childhood and Adolescence. Nutrition Reviews, 60, S77-S83. https://doi.org/10.1301/00296640260130795

[4] SCN Standing Committee on Nutrition (2002) School Age Children: Their Health and Nutrition. SCN News, 25, 1-78.

[5] Chadha, M.L., Engle, L.M., Hughes, J.A., Ledesma, D.R. and Weinberger, K.M. (2007) AVRDC-The World Vegetable Center's Approach to Alleviate Malnutrition. In: Thompson, B. and Amoroso, L., Eds., Combating Micronutrient Deficiencies. Food-Based Approaches, FAO, Rome, 183-197.

[6] WHO/FAO World Health Organization/Food and Agriculture Organization of the United Nations (2004) Vitamin and Mineral Requirements in Human Nutrition. WHO, Geneva.

[7] USDA United States Department of Agriculture (2014) National Nutrient Database for Standard Reference. Release 27.

[8] Muyonga, J.H., Nabakabya, I.D., Nakimbugwe, D.N. and Masinde, D. (2008) Efforts to Promote Amaranth Production and Consumption in Uganda to Fight Malnutrition. In: Robertson, G.L. and Lupien, J.R., Eds., Chapter 8 Using Food Science and Technology to Improve Nutrition and Promote National Development, International Union of Food Science and Technology, Toronto, 1-10.

[9] Singh, H., Bawa, A.S. and Ahmed, J. (1997) Dehydration Characteristics of Green Leafy. Indian Food Packer, 51, 5-13.

[10] IITA International Institute of Tropical Agriculture (1990) Soybeans for Good Health: How to Grow and Use Soybeans in Nigeria. IITA Publication, Ibadan, 23.

[11] Akpapunam, M.A., Badifu, G.I.O. and Etokudo, E.P. (1997) Production and Quality Characteristics of Nigerian "Agidi” Supplemented with Soy Flour. Journal of Food Science and Technology, 34, 143-145.

[12] Mais, A. (2008) Utilization of Sweet Potato Starch, Flour and Fibre in Bread and Biscuits: Physicochemical and Nutritional Characteristics. Master's Thesis, Massey University, Massey.

[13] Rakcejeva, T., Galoburda, R., Cude L. and Strautniece, E. (2011) Use of Dried 
Pumpkins in Wheat Bread Production. Procedia Food Science, 1, 441-447. https://doi.org/10.1016/j.profoo.2011.09.068

[14] Que, F., Mao, L., Fang, L. and Wu, T. (2008) Comparison of Hot Air-Drying and Freeze-Drying on the Physicochemical Properties and Antioxidant Activities of Pumpkin (Cucurbita moschata Duch.) Flours. International Journal of Food Science and Technology, 43, 1195-1201. https://doi.org/10.1111/j.1365-2621.2007.01590.x

[15] Concept 4 Creative Software, Creative Formulation Concepts, LLC, Educational version 8.01.01, Annapolis.

[16] Bechoff, A., Poulaert, M., Tomlins, K.I., Westby, A., Menya, G., Young, S. and Dhuique-Mayer, C. (2011) Retention and Bioaccessibility of $\beta$-Carotene in Blended Foods Containing Orange-Fleshed Sweet Potato Flour. Journal of Agricultural and Food Chemistry, 59, 10373-10380. https://doi.org/10.1021/jf201205y

[17] Tibagonzeka, J. (2014) Potential of Grain Amaranth to Improve Food and Nutrition Security in Rural Uganda. Master's Thesis. Makerere University Kampala Uganda, Uganda. http://hdl.handle.net/10570/3274

[18] Mosha, A. and Svanberg, U. (1983) Preparation of Weaning Foods with High Nutrient Density Using Flour of Germinated Cereals. Food and Nutrition Bulletin, 5, $10-14$.

[19] Thaoge M.L., Adams, M.R., Sibara, M.M., Watson, T.G., Taylor, J.R.N. and Goyvaerts, E.M. (2003) Production of Improved Infant Porridge from Pearl Millet Using a Lactic Acid Fermentation Step and Addition of Sorghum Malt to Reduce Viscosity of Porridges with High Protein, Energy and Solids (30\%). World Journal of Microbiology and Biotechnology, 19, 305-310. https://doi.org/10.1023/A:1023614526667

[20] Larmond, E. (1977) Laboratory Methods for Sensory Evaluation of Food. Research Branch, Canada Department of Agriculture, Publication No. 1637, 19-63.

[21] Guinard, J. (2001) Sensory and Consumer Testing with Children: A Review. Trends in Food Science \& Technology, 11, 273-283. https://doi.org/10.1016/S0924-2244(01)00015-2

[22] Dawn, M., Stephenson, J.M., Meeks, G., Susan, P.W. and Ashworth, A. (1994) Weaning-Food Viscosity and Energy Density: Their Effects on Ad Libitum Consumption and Energy Intakes in Jamaican Children. American Journal of Clinical Nutrition, 60, 465-469.

[23] Newport Scientific (1998) Applications Manual for the Rapid Visco Analyzer Using Thermocline for Windows. Newport Scientific Pty Ltd., Warriewood, 2-26.

[24] AOAC Association of Official Analytical Chemists (1990) Official Method of Analysis. 14th Edition, Association of Official Analytical Chemists, Washington DC.

[25] AOAC (1999) Official Methods of Analysis. 16th Edition, AOAC International, Gaithersburg.

[26] Kirk, R.S. and Sawyer, R. (1991) Fats and Oils. In: Mansour, E.H., Dworschsk, E., Lugasi, A. and Barna, E., Eds., Pearson's Composition and Analysis of Foods, 9th Edition, Longman Group Limited, Harlow, 641.

[27] Merrill, A.L. and Watt, B.K. (1973) Energy Value of Foods: Basis and Derivation. Agriculture Handbook. US Department of Agriculture, Agricultural Research Service, Washington DC.

[28] Kimura, M., Kobori, C.N., Rodriguez-Amaya, D.B. and Nestel, P. (2004) Screening and HPLC for Sweet Potato, Cassava and Maize. (Unpublished)

[29] Rodriguez-Amaya, D.B. (1999) A Guide to Carotenoids Analysis in Foods. ILSI Press, Washington DC. 
[30] Okalebo, J.R., Gathua, K.W. and Lwoomer, P. (2002) Laboratory Methods for Soil and Plant Analysis: Determination of Minerals, Ch. 20.

[31] Duhan, A., Khetarpaul, N. and Bishnoi, S. (2002) Changes in Phytates and HCl-Extractability of Calcium, Phosphorus and Iron of Soaked, Dehulled, Cooked and Sprouted Pigeon Pea Cultivar. Plant Food Human Nutrition, 57, 275-284. https://doi.org/10.1023/A:1021814919592

[32] Amegovu, A.K., Ogwok, P., Ochola, S., Yiga, P., Musalima, J.H. and Mandha, J. (2014) Sensory Acceptability of Sorghum Peanut Blend (SPB) and Corn Soy Blend Plus (CSB+) By Young Children with Moderate Acute Malnutrition in Karamoja, Uganda. Journal of Food Research, 3, 17-26. https://doi.org/10.5539/jfr.v3n2p17

[33] FNB Food and Nutrition Board (2003) Dietary Reference Intakes: Guiding Principles for Nutrition Labeling and Fortification. The National Academies Press Washington DC. www.nap.edu

[34] Edda, L. (2013) Development and Evaluation of the Physical, Chemical and Sensory Properties of Two Weaning Foods to Improve the Nutritional Intake of Malawian Children. Master's Thesis, Michigan State University, Michigan. http://etd.lib.msu.edu/islandora/object/etd\%3A2279/datastream/OBJ/view

[35] Rangel, C.N., Silva, E., Salvador, L., Figueiredo, R., Watanabe, E., Silva, J., Carvalho, J. and Nutti, M.R. (2011) Sensory Evaluation of Cakes Prepared with OrangeFleshed Sweet Potato Flour (Ipomoeas batatas L.). Perspectives in Human Nutrition, 13, 203-211.

[36] Borneo, R. and Aguirre, A. (2008) Chemical Composition, Cooking Quality, and Consumer Acceptance of Pasta made with Dried Amaranth Leaves Flour. LWTFood Science and Technology, 41, 1748-1751. https://doi.org/10.1016/j.lwt.2008.02.011

[37] CODEX Alimentarius Commission, Joint FAO/WHO Food Standards Programme (2013) Codex General Standard for Soy Protein Products. http://www.fao.org/input/download/standards/325/CXS_175e.pdf

[38] Tang, G. (2013) Using Plant Foods Rich in $\beta$-Carotene to Combat Vitamin A Deficiency. Sight and Life, Switzerland, 27.

[39] Igbabul, B., Num, G. and Amove, J. (2014) Quality Evaluation of Composite Bread Produced from Wheat, Maize and Orange Fleshed Sweet Potato Flours. American Journal of Food Science and Technology, 2, 109-115. http://pubs.sciepub.com/ajfst/2/4/1

[40] Gupta, S. and Prakash, J. (2011) Nutritional and Sensory Quality of Micronutrient-Rich Traditional Products Incorporated with Green Leafy Vegetables. International Food Research Journal, 18, 667-675.

[41] Chiplonkar, S.A., Tarwadi, K.V., Kavedia, R.B., Mengale, S.S., Paknikar, K.M. and Agte V.V. (1999) Fortification of Vegetarian Diets for Increasing Bioavailable Iron Density Using Green Leafy Vegetables. Food Research International, 32, 169-174. https://doi.org/10.1016/S0963-9969(99)00070-8

[42] Schlemmer, U., Frolich, W., Prieto, R.M. and Grases, F. (2009) Phytate in Foods and Significance for Humans: Food Sources, Intake, Processing, Bioavailability, Protective Role and Analysis. Molecular Nutrition and Food Research, 53, S330-S375. https://doi.org/10.1002/mnfr.200900099

[43] Cercamondi, C.I., Egli, I.M., Mitchikpe, E., Tossou, F., Hessou, J., Zeder, C., Hounhouigan, J.D. and Hurrell, R.F. (2013) Iron Bioavailability from a Lipid-Based Complementary Food Fortificant mixed with Millet Porridge Can Be Optimized by Adding Phytase and Ascorbic Acid But Not by Using a Mixture of Ferrous Sulfate and Sodium Iron EDTA. Journal of Nutrition, 143, 1233-1239.

https://doi.org/10.3945/jn.113.175075 
Submit or recommend next manuscript to SCIRP and we will provide best service for you:

Accepting pre-submission inquiries through Email, Facebook, LinkedIn, Twitter, etc. A wide selection of journals (inclusive of 9 subjects, more than 200 journals)

Providing 24-hour high-quality service

User-friendly online submission system

Fair and swift peer-review system

Efficient typesetting and proofreading procedure

Display of the result of downloads and visits, as well as the number of cited articles Maximum dissemination of your research work

Submit your manuscript at: http://papersubmission.scirp.org/

Or contact fns@scirp.org 